\title{
Perilaku Menggunakan Kondom pada Wanita Penjaja Seks Jalanan di Jakarta Timur Tahun 2006
}

\author{
Widyastuti*
}

\begin{abstract}
Abstrak
Infeksi Menular Seksual (IMS) di banyak negara merupakan ancaman serius global yang berdampak pada individu, keluarga dan masyarakat. Pada perempuan, IMS sulit didiagnosa dan berdampak lebih besar, karena umumnya tampa gejala, timbul rasa bersalah dan malu mencari pengobatan sehingga menjadi beban tersembunyi. Prevalensi IMS dari berbagai penelitian di Indonesia pada periode 1990-2000 relatif tinggi. Strategi memutuskan rantai penularan antara lain melalui promosi kondom khususnya pada Wanita Penjaja Seks (WPS) yang berisiko tinggi IMS. Penelitian ini bertujuan mengetahui berbagai faktor yang berhubungan dengan perilaku pemakaian kondom pada Wanita Pekerja Seks jalanan di Jakarta Timur tahun 2006. Penelitian dengan rancangan studi cross sectional ini menggunakan data primer 112 Wanita Pekerja Seks jalanan. Hasil penelitian menunjukkan bahwa terdapat 60,7\% responden yang menggunakan kondom pada saat hubungan seks terakhir. Hasil analisis multivariat menunjukkan bahwa pengalaman menderita IMS merupakan faktor yang paling dominan dengan OR sebesar 3,55. Variabel umur, tingkat pendidikan, lama bekerja sebagai WPS, pengetahuan tentang IMS, serta keterpaparan informasi tidak berhubungan secara bermakna dengan perilaku menggunakan kondom. Disarankan mempermudah akses terhadap kondom, meningkatkan kualitas maupun kuantitas KIE; menjalin kemitraan dengan berbagai pihak terkait; dan pemberdayaan WPS dalam kegiatan penyebarluasan informasi tentang IMS dan kondom.
\end{abstract}

Kata kunci : Perilaku, kondom, wanita pekerja seks jalanan, IMS

\begin{abstract}
In most countries in the world, sexually transmitted infections (STIs) are considered as a serious threat, they pose great impact on individual, family, and community. The impacts of STIs on women are usually more severe and more difficult to be diagnosed than impacts on men because STIs usually occurred without observable symptoms, and usually woman has guilty feeling and embarrassed about their condition and thus hinder them to look for medication. These make STIs a hidden burden for women. Prevalence of STIs in Indonesia according to several studies in 1990-2000 periods is quite high. One strategy to break the infection chain is to promote condom use among women sex workers (WSW). This study aims at investigating factors related to condom use practice among street WSW in East Jakarta. The design of this study is cross-sectional with quantitative approach, and using primary data of 112 street WSW. The study found that there are $60.7 \%$ respondents who use condom in the last sexual activity. Multivariate analysis shows that the most dominant factor is the experience on suffering from STIs infection, with OR 3.55. Age, level of education, working duration as WSW, knowledge on STIs, and exposure on STIs information, all have no statistically significant relationship with condom use practice. It is suggested that to increase the access and availability of condom, to increase the quality and quantity of information, education, and communication activities by strengthening networking and partnership with related sectors, and to empower the WSW themselves on disseminating and spreading information on STIs and condom.
\end{abstract}

Key words : Behavior, condom, street woman sex workers, STIs

*Kepala Seksi Penyakit Menular Suku Dinas Kesehatan Masyarakat Jakarta Timur 
Infeksi Menular Seksual (IMS) di banyak negara dianggap sebagai ancaman global yang serius, dengan dampak pada individu, keluarga maupun masyarakat. Di beberapa negara, IMS beserta komplikasinya menduduki peringkat ke lima utama alasan berobat bagi penduduk usia dewasa. ${ }^{1}$ Dampak IMS pada perempuan biasanya lebih berat dan sulit didiagnosa, karena umumnya tidak menunjukkan gejala (asimptomatik), timbul rasa bersalah atau malu untuk mencari pengobatan, sehingga IMS menjadi beban tersembunyi bagi perempuan. ${ }^{2}$

Angka prevalensi IMS dari berbagai penelitian di Indonesia antara tahun 1990-2000 pada wanita Penjaja seks (WPS) relatif tinggi. ${ }^{3}$ Prevalensi gonore adalah 0,5$20 \%$, sifilis $0,5-10,8 \%$, dan infeksi HIV/AIDS 1$26,5 \%$. Angka prevalensi ini lebih tinggi dibandingkan target Departemen Kesehatan dalam kebijaksanaan programnya pada kelompok perilaku risiko tinggi, yaitu menjadi kurang dari $1 \%$ untuk sifilis, kurang dari $10 \%$ untuk gonore dan tidak melebihi $1 \%$ untuk infeksi HIV. ${ }^{4}$ Salah satu strategi yang dikembangkan dalam memutuskan rantai penularan IMS ini adalah pencegahan penularan melalui hubungan seksual, antara lain dengan kegiatan promosi kondom pada kelompok berperilaku risiko tinggi, termasuk terhadap Wanita Penjaja Seks (WPS) di jalanan yang keberadaannya sulit diidentifikasi sementara transaksi seks diantara mereka cukup tinggi dan rawan terkena IMS.

Beberapa penelitian menunjukkan bahwa upaya pencegahan yang diyakini dan dilakukan oleh WPS supaya terhindar dari IMS sangat bervariasi dan tidak tepat secara medis, seperti mempertimbangkan bentuk fisik pelanggan, minum jamu tradisional, bilas vagina ( $\mathrm{dou}$ ching), dan minum antibiotika tidak sesuai dosis, sementara pemakaian kondom relatif rendah. ${ }^{5}$ Survei Surveilans Perilaku (SSP) tahun 1998 oleh Pusat Peneilitian Kesehatan Universitas Indonesia menggambarkan 53\% pelanggan dilaporkan WPS menggunakan kondom pada hubungan seks terakhir. ${ }^{6}$ Hasil survei Departemen Kesehatan tahun 2004 di sembilan propinsi prioritas menunjukkan penggunaan kondom pada seks komersial sebesar 59,7\%.7

Menurut Pusat Data dan Informasi Kesejahteraan Sosial Departemen Sosial, pada tahun 2004 jumlah WPS di Indonesia sebanyak 87.536 orang. Jumlah WPS di DKI Jakarta menduduki peringkat kedua yaitu sebanyak 9519 orang, dan sebagian besar berada di Jakarta Timur yaitu sebesar 2264 orang. Berdasarkan hal tersebut di atas maka peneliti ingin mengetahui bagaimana gambaran perilaku pemakaian kondom pada WPS jalanan di Jakarta Timur dan faktor-faktor yang mempengaruhinya seperti umur WPS, lama bekerja, pendidikan, tingkat pengetahun, sikap terhadap kondom, riwayat menderita IMS sebelumnya, keterpaparan informasi dan ketersediaan kondom. Hasil penelitian ini diharapkan bisa digunakan sebagai bahan informasi dalam penetapan kebijakan program pengendalian IMS.

\section{Metode}

Penelitian ini menggunakan rancangan cross sectional dan dilakukan pada bulan April-Mei 2006 di Jakarta Timur melalui pendekatan kuantitatif, dengan menggunakan data primer dan jumlah sampel 112 Wanita Penjaja Seks jalanan yang didapatkan secara snow ball dengan informasi awal dari Yayasan Bandungwangi. Pengumpulan data dilakukan dengan wawancara menggunakan kuesioner terstruktur yang disusun berdasarkan hasil observasi lapangan oleh peneliti, diskusi kelompok terarah dengan WPS dan mantan WPS diluar lokasi penelitian serta modifikasi dari beberapa penelitian sebelumnya. Terdapat 97 pertanyaan yang terbagi atas 7 bagian, yaitu karakteristik sosiodemografi, pengetahuan tentang IMS, sikap terhadap kondom, pengalaman menderita IMS, keterpaparan informasi, ketersedian kondom dan perilaku pemakaian kondom. Untuk menjamin validitas dan reliabilitas kuesioner, dilakukan uji coba kuesioner terhadap 30 WPS jalanan yang menjadi siswa binaan di Panti Sosial Karya Wanita (PSKW) Mulya Jaya Jakarta.

Analisis data dilakukan dengan perangkat lunak komputer menggunakan program SPSS, meliputi: Analisis Univariat untuk melihat gambaran distribusi frekuensi masing-masing variabel penelitian sehingga dapat diketahu variasi dari masing-masing variabel. Analisis Bivariat untuk melihat hubungan antara variabel independen dan dependen dan mengetahui apakah hubungan yang terjadi bermakna secara statistik atau tidak. Uji statistik yang digunakan adalah chi-square, dengan derajat kemaknaan 0,05 . Apabila nila $\mathrm{p}<0,05$ maka secara statistik bermakna yang artinya terdapat hubungan antara variabel independen dengan dependen. Analisis Multivariat dengan menggunakan regresi logistik untuk mengetahui faktor yang benar-benar berhubungan dengan pengunaan kondom.

\section{Hasil}

\section{Analisis Univariat}

Variabel dependen penelitian ini adalah pemakaian kondom pada hubungan seks terakhir. Untuk menilai konsistensi juga ditanyakan pemakaian kondom pada satu minggu terakhir maupun pada hari kerja terakhir. Pemakaian kondom dibedakan atas tidak pernah, jika dalam seminggu terakhir sama sekali tidak memakai kondom $(0 \%)$, jarang jika pemakaian kondom kurang < $50 \%$ dari jumlah tamu; sering jika pemakaian kondom dilakukan pada $50-<100 \%$ tamu; selalu jika $100 \%$ tamu menggunakan kondom. Pemakaian kondom pada hari kerja terakhir dibedakan atas; selalu jika semua tamu kawan kencan pada hari tersebut memakai kondom dan 
tidak selalu jika tidak semua tamu pada hari tersebut memakai kondom. Penelitian ini memperlihatkan angka pemakaian kondom yang sangat bervariasi. Selama seminggu terakhir, yang selalu memakai kondom sebanyak $27 \%$, hari kerja terakhir sebanyak $46,4 \%$ dan saat hubungan seks terakhir yang menggunakan kondom sebanyak 60,7\%. (Lihat Tabel 1)

Hasil analisis menunjukkan bahwa umur responden rata-rata adalah 30 tahun, termuda 16 tahun dan tertua 56 tahun. Sebagian besar responden bermur 30-39 tahun $(38,4 \%)$ dan latar belakang pendidikan tamat SD $(39,3 \%), 13,4 \%$ diantaranya tidak pernah sekolah. Lama kerja sebagai WPS sebagian besar adalah $\geq 24$ bulan $(61,6 \%)$. Sekitar 50\% responden mempunyai tingkat pengetahuan kurang sampai buruk (skor 0-14). Berdasarkan skala likert, dengan cut off point nilai mean (110), sebagian besar $(51,8 \%)$ tidak mendukung. Debagian besar responden $(58,9 \%)$ pernah mengalami gejala IMS dan sebagian besar responden $(86,6 \%)$ sebelumnya pernah mendapatkan informasi tentang IMS. Sebagian besar responden $(52,7 \%)$ menyatakan kondom selalu tersedia disekitar lokasi mejeng dan tempat hubungan seksual (lihat tabel 2).

\section{Seleksi Variabel Kandidat Model}

Hubungan antara variabel independen dan dependen dilihat secara statistik melalui analisis bivariat dengan uji chi-square. Hasil kemaknaan perhitungan statistik antara variabel dependen dan variabel independen digunakan batas kemaknaan 0,05. Uji statistik dinyatakan bermakna bila nilai $p$ value lebih kecil dari $\alpha(p<0,05)$, sebaliknya apabila $\mathrm{p}>\alpha(\mathrm{p}>0,05)$ dinyatakan tidak bermakna. Semua variabel diklasifikasikan menjadi dua, sehingga semua berjenis katagorik dan dianalisis dengan tabel $2 \times 2$. Variabel umur dikategorikan menjadi dua dengan cut off point batas umur remaja sesuai definisi WHO (1024 tahun), yaitu $\leq 24$ tahun dan $>24$ tahun. Sedangkan pendidikan responden diklasifikasikan menjadi dua dengan cut off point wajib belajar 9 tahun (SLTP) sesuai dengan UU Republik Indonesia No.20 Tahun 2003 tentang Sistem Pendidikan Nasional.

Hasil uji chi-square menunjukkan adanya tiga variabel independen yang berhubungan dengan perilaku pemakain kondom pada hubungan seks terakhir. Variabel tersebut adalah sikap responden terhadap kondom $(\mathrm{p}=$ $0,027)$, pengalaman menderita IMS $(P=0,003)$ dan ketersediaan kondom disekitar lokasi mejeng atau di tempat mengadakan hubungan seksual $(0,028)$ seperti yang tercantum pada tabel 3 .

\section{Analisis Multivariat}

Analisis multivariat dilakukan dengan uji regresi logistik dengan tiga tahap sebagai berikut: Tahap pertama, Seleksi kandidat variabel independen melalui analisis bi-
Tabel 1. Distribusi Responden Menurut Pemakaian Kondom $(n=112)$

\begin{tabular}{llll}
\hline Pemakaian Kondom & Katagori & n & $\%$ \\
\hline Dalam Seminggu Terakhir & Tak Pernah $(0 \%)$ & 14 & 12,5 \\
& Jarang $(>0 \%$ sd $<50 \%)$ & 52 & 46,4 \\
& Sering $(\geq 50 \%$ sd $100 \%)$ & 15 & 13,4 \\
\multirow{5}{*}{ Pada Hari Kerja Terakhir } & Selalu $(100 \%)$ & 31 & 27,7 \\
Pada Seks Terakhir & Selalu & 52 & 46,4 \\
& Tidak Selalu & 60 & 53,6 \\
& Ya & 68 & 60,7 \\
& Tidak & 44 & 39,3 \\
\hline
\end{tabular}

Tabel 2. Distribusi Responden Menurut Berbagai Variabel Independen $(\mathrm{n}=112)$

\begin{tabular}{|c|c|c|c|}
\hline Variabel Independen & Katagori & $\mathbf{n}$ & $\%$ \\
\hline \multirow[t]{3}{*}{ Umur } & $<20$ tahun & 12 & 10,7 \\
\hline & 20-29 tahun & 40 & 35,7 \\
\hline & $\geq 30$ tahun & 60 & 63,6 \\
\hline \multirow[t]{5}{*}{ Pendidikan } & Tidak sekolah & 15 & 13,4 \\
\hline & Tidak tamat SD & 27 & 24,1 \\
\hline & Tamat SD & 44 & 39,3 \\
\hline & Tamat SLTP & 21 & 18,8 \\
\hline & Tamat SLTA & 5 & 4,5 \\
\hline \multirow[t]{2}{*}{ Lama Bekerja } & $\geq 24$ Bulan & 69 & 61,6 \\
\hline & $<24$ Bulan & 43 & 38,4 \\
\hline \multirow[t]{4}{*}{ Pengetahuan } & Buruk (0-7) & 15 & 13,4 \\
\hline & Kurang (8-14) & 57 & 50,9 \\
\hline & Cukup (15-21) & 35 & 31,3 \\
\hline & Baik (22-28) & 5 & 4,5 \\
\hline \multirow[t]{2}{*}{ Sikap Terhadap Kondom } & Mendukung & 54 & 48,2 \\
\hline & Tidak Mendukung & 58 & 51,8 \\
\hline \multirow[t]{2}{*}{ Pengalaman IMS } & Pernah & 66 & 58,9 \\
\hline & Tidak Pernah & 46 & 41,1 \\
\hline \multirow[t]{2}{*}{ Pajanan informasi } & Terpapar & 97 & 86,6 \\
\hline & Tidak Terpapar & 15 & 13,4 \\
\hline \multirow[t]{2}{*}{ Ketersediaan Kondom } & Tersedia & 59 & 52,7 \\
\hline & Tidak Tersedia & 53 & 47,3 \\
\hline
\end{tabular}

Tabel 3. Hasil Analisis Bivariat untuk Seleksi Variabel Kandidat Model

\begin{tabular}{lll}
\hline Variabel (n=112) & Katagori & Nilai P \\
\hline Umur & $\leq 24$ tahun & 0,264 \\
& $>24$ tahun & \\
Pendidikan & $\geq$ SLTP & 0,743 \\
& $\leq$ SD & \\
Lama Kerja & $<24$ bulan & 0.58 \\
Pengetahuan & $\geq 24$ bulan & \\
Sikap & Kurang & 0,29 \\
Pengalaman IMS & Baik & \\
Paparan Informasi & Mendukung & $\mathbf{0 , 0 2 7}$ \\
& Tidak mendukung & \\
Ketersediaan Kondom & Pernah & $\mathbf{0 , 0 0 3 *}$ \\
& Tidak Pernah & \\
& Tidak Terpapar & \\
& Terpapar & 0,429 \\
& Tersedia & $\mathbf{0 , 0 2 8 *}$ \\
& Tidak Tersedia &
\end{tabular}

$* \mathrm{p}$ value $\leq 0,05$, berarti ada hubungan yang bermakna antara variabel dependen dengan variabel independen. 
variat. Apabila hasil uji bivariat mempunyai nilai $\mathrm{p}<$ 0,25 , maka variabel tersebut masuk dalam model analisis multivariat. Dari delapan variabel independen, terdapat lima variabel yang masuk ke dalam model, yaitu umur, pengetahuan tentang IMS, sikap terhadap kondom, pengalaman menderita IMS, dan ketersediaan kondom. Tahap kedua, model terbaik akan mempertimbangkan nilai signifikansi ratio log-likehood $(\mathrm{p} \leq 0,05)$ dan nilai signifikansi $\mathrm{p}$ value $\leq 0,05$. Lima variabel independen yang memenuhi syarat sesuai hasil uji bivariat diuji secara bersama-sama. Variabel dengan nilai $\mathrm{p}$ wald tidak signifikan dikeluarkan dari model secara berurutan, dimulai dari variabel dengan $\mathrm{p}$ wald terbesar. Pada tahap ini tinggal dua variabel yang hubungannya bermakna dengan penggunaan kondom, yaitu pengalaman menderita IMS dan ketersediaan kondom. Tahap ketiga, Uji interaksi dilakukan terhadap dua variabel yang mempunyai hubungan bermakna, yaitu pengalaman menderita IMS dan ketersediaan kondom.

Berdasarkan proses analisis multivariat didapatkan bahwa dari delapan variabel independen, ternyata ada dua variabel independen yang secara signifikan berhubungan dengan perilaku pemakaian kondom pada hubungan seks terakhir, yaitu pengalaman menderita IMS dan ketersediaan kondom. Responden yang pernah menderita IMS berpeluang meggunakan kondom 3,55 kali lebih besar (95\% CI: 1,56-8,07) dibandingkan responden yang tidak pernah menderita IMS setelah dikontrol dengan variabel ketersediaan kondom. Apabila disekitar tempat kerja atau disekitar lokasi mejeng maupun ditempat melakukan hubungan seks tersedia kondom, maka peluang responden untuk menggunakan kondom 2,65 kali lebih besar (95\% CI: 1,167 - 6,003) dibandingkan tidak tersedia kondom, setelah dikontrol dengan pengalaman responden menderita IMS. Variabel pengalaman menderita IMS merupakan variabel yang paling dominan berhubungan dengan perilaku pemakaian kondom pada Wanita Penjaja Seks jalanan.

\section{Pembahasan \\ Keterbatasan Penelitian}

Keterbatasan penelitian ini antara lain adalah hasil yang dicapai merupakan gambaran sesaat, tidak mampu menjelaskan urutan waktu antara variabel dependen dan variabel independen. Karena jumlah WPS jalanan belum diketahui, akses ke WPS jalanan yang sulit, maka penarikan sampel dilaksanakan secara snow ball kepada WPS jalanan yang bersedia diwawancara. Jumlah variabel yang diteliti hanya 8 variabel independen, sehingga masih banyak variabel lainnya yang belum diteliti sesuai dengan teori tentang perilaku. Kualitas dan akurasi data sangat dipengaruhi oleh kejujuran pewawancara dan responden serta daya ingat responden. Pembobotan jawaban setiap pertanyaan pengetahuan responden sama besar, se- hingga pertanyaan sulit dan mudah dianggap sama. Bias informasi dapat pula terjadi terutama pada variabel pengalaman menderita IMS, dan lama bekerja.

Didapatkan $7,1 \%$ responden yang sama sekali tidak melakukan upaya pencegahan penularan IMS dengan alasan tidak punya biaya dan tidak tahu harus melakukan apa. Hal ini mungkin berhubungan dengan tingkat sosial ekonomi yang rendah tidak pernah sekolah $(13,4 \%)$. Selain itu, lama bekerja sebagai WPS kurang dari 3 bulan $(9,9 \%)$, sehingga interaksi dengan LSM maupun sesama WPS masih kurang. Pendapatan responden (ratarata Rp. 600.000,- perbulan) berada di atas gaji pembantu rumah tangga baru di Jakarta (Rp.250.000,- - Rp. 400.000,-) tetapi berada di bawah UMP Jakarta (Rp.819.250,-). Meskipun sekitar 12,5\%, responden berpenghasilan Rp.2.000.000,- - Rp.5.000.000, per bulan yang lebih besar dari gaji PNS baru golongan III. Selain itu, sekitar $79,5 \%$ responden mempunyai anak dan $75 \%$ diantaranya diurus sendiri dan sekitar 35,7\% berperan sebagai orang tua tunggal.

Sebanyak 104 responden mengatakan melakukan upaya pencegahan penularan IMS, sekitar 94,2\% di antaranya mengaku menggunakan kondom. Selain itu mereka juga melakukan upaya lain seperti minum ramuan tradisional, mencuci alat kelamin dengan odol/sabun sirih/ cairan antiseptik, mencuci alat kelamin tamu, tidak melakukan hubungan seks dengan tamu yang terlihat kotor, minum antibiotika, memeriksakan diri ke petugas kesehatan. Perilaku pencegahan ini senada dengan hasil penelitian kualitatif yang dilakukan di Jakarta oleh Kresno ${ }^{5}$ dan Sedyaningsih ${ }^{8}$ pada WPS di lokalisasi.

Jika dibandingkan pemakaian dalam satu minggu terakhir, hari kerja terakhir dan hubungan seks terakhir, terlihat bahwa pemakaian kondom tidak konsisten. Berdasarkan analisis deskriptif perilaku pemakaian kondom pada saat seks terakhir adalah $60,7 \%$ yang sebagian besar merupakan inisiatif responden (90\%). Responden yang selalu menggunakan kondom pada saat berhubungan seks pada hari terakhir dan minggu terakhir adalah $46,4 \%$ dan $27,7 \%$. Pemakaian kondom pada satu minggu terakhir memperlihatkan angka yang lebih tinggi daripada penelitian lain. Badan Pusat Statistik dan Departemen Kesehatan di berbagai kota di Indonesia, (4\%-20\%).9,10 Tetapi beberapa penelitian justru menemukan angka pemakaian kondom yang lebih besar yang berkisar antara 44\%-56\%.6,9,11 Untuk pemakain kondom pada hari terakhir, ada perbedaan yang tidak mencolok dengan beberapa penelitian lain di Kalimantan dan di Jakarta dengan kisaran 45,3\%- 53\%.12,13 Sedangkan pemakain kondom pada seks terakhir pada penelitian ini $(60,7 \%)$ terlihat lebih tinggi dari penelitian-penelitian serupa oleh PPK UI6 tahun 1998 (52,8\% ).

Beberapa faktor yang mungkin berpengaruh terhadap perbedaan angka tersebut antara lain: Pertama, perbe- 
daan sasaran penelitian. Penelitian ini adalah WPS jalanan sedangkan pada penelitian lain adalah WPS di lokalisasi. Kedua, bias informasi, khususnya pada perilaku pemakaian kondom selama satu minggu terakhir. Untuk WPS yang mempunyai banyak pasangan seksual. Pada penelitian ini, jumlah tamu selama satu minggu terakhir berkisar antara 1-30 orang dengan hari kerja 2-7 hari per minggu. Ketiga, kejujuran jawaban responden. Dari beberapa penelitian sebelumnya didapatkan angka yang berbeda antara jawaban responden dengan jawaban tamu responden. ${ }^{6,13}$ Keempat, waktu penelitian yang berbeda jauh. Hal ini berhubungan dengan program promosi kondom yang semakin gencar dan upaya pemerintah merangkul LSM dan media massa.

Semua responden mengatakan bahwa alasan memakai kondom adalah untuk menghindari penularan IMS dan untuk menghindari kehamilan. Sedangkan 44 responden yang tidak menggunakan kondom pada hubungan seks terakhir $(48,5 \%)$, sebagian besar responden yang tidak memakai kondom $(79,5 \%)$ beralasan pasangan tidak mau memakai kondom. Alasan utama tidak memakai kondom ini sama dari berbagai penelitian sebelumnya. Hal ini disebabkan oleh kemampuan bernegosiasi dan posisi tawar WPS yang lemah sehubungan dengan ketergantungan ekonomis responden pada pelanggan. Temuan ini sesuai dengan hasil penelitian Kresno. ${ }^{5}$ Upaya yang dilakukan responden untuk menggunakan kondom pada tamu yang menolak memakai kondom, adalah merayu tamu $(51,8 \%)$. Sebagian responden khususnya yang berumur muda, secara tegas menyatakan berani menolak tamu yang tidak memakai kondom. Sedangkan yang menyatakan menurunkan tarif untuk tamu menolak menggunakan kondom adalah $(12,5 \%)$.

Sebagian besar responden mendapatkan kondom dari yayasan dan LSM $(56,3 \%)$, sebagaian kecil dari rumah sakit atau Puskesmas $(1,8 \%)$ serta tidak ada satupun dari ATM kondom. Hal ini terjadi karena LSM bergerak dalam program pendampingan, memakai tenaga dari kalangan mereka atau bahkan mantan WPS itu sendiri. Sebagai contoh, Yayasan Bandungwangi, di Jakarta Timur hanya satu Puskesmas yang mempunyai klinik khusus pelayanan IMS, sementara Puskesmas lain belum melakukan upaya proaktif tersebut. Selain itu, ATM kondom berada jauh dari tempat lokalisasi atau tempat para WPS mejeng.

Penelitian ini menemukan responden berumur $>24$ tahun $(75 \%)$ lebih tinggi daripada yang berumur $\leq 24$ tahun. Hal tersebut berbeda dengan penelitian WPS di lokalisasi yang menemukan sebagian besar responden berumur $\leq 24.8,10,12,14,15$ Dengan hasil uji statistik yang tidak bermakna, nilai $\mathrm{p}=0,264 ; \mathrm{OR}=1,87(95 \%$ CI: $0,74-4,72)$. Hal ini sejalan dengan hasil penelitian Sedyaningsih, ${ }^{8}$ Soelistijani ${ }^{10}$ terhadap WPS di Bali, survei PPK UI ${ }^{6}$ di Jakarta dan Riau, Iskandar, ${ }^{11}$ dan Kalsum. ${ }^{16}$

Penelitian yang menemukan pendidikan WPS rendah ini sesuai dengan laporan Sedyaningsih ${ }^{8}$ di Kramat Tunggak, Soelistijani ${ }^{10}$ di Bali, Mardjan ${ }^{12}$ di lokalisasi Sambas, Suyanto,dkk ${ }^{14}$ di Baturaden, dan laporan Yustikawati ${ }^{15}$ di Indramayu. Umumnya WPS berpendidikan $\leq$ SD. Hasil uji statistik diperoleh nilai $p=0,743$, yang berarti tidak terdapat hubungan bermakna antara tingkat pendidikan dengan perilaku pemakaian kondom. Hasil tersebut sesuai dengan hasil penelitian Soelistijani ${ }^{10}$ di Bali, Mardjan, ${ }^{12}$ Kalsum ${ }^{16}$ serta Mulyati ${ }^{17}$ di Cilengsi Bogor. Hasil yang berbeda dilaporkan oleh Iskandar, ${ }^{11}$ faktor pendidikan mempunyai hubungan yang bermakna dengan keinginan memakai kondom. Kemungkinan faktor lain adalah persaingan bisnis atau transaksi seks antara WP yang ketat, sehingga mereka lebih mengutamakan kepuasan "tamu" dari pada melindungi diri.

Sebagian besar responden $(86,6 \%)$ mengatakan pernah mendapatkan informasi tentang IMS maupun kondom. Angka ini jauh lebih tinggi dibandingkan hasil penelitian Yustikawati ${ }^{15}$ terhadap WPS di Indramayu $(33,1 \%)$. Tiga sumber informasi yang paling sering secara langsung memberikan penyuluhan kepada responden adalah yayasan atau LSM $(83,5 \%)$, teman sesama WPS $(38,1 \%)$ dan dokter praktek swasta (34\%). Sedangkan sumber informasi yang jarang memberikan penyuluhan kepada responden adalah Puskesmas $(7,2 \%)$ dan Dinas Sosial (3\%). Hal ini kemungkinan karena program pembinaan terhadap WPS yang dilakukan oleh Puskesmas maupun Dinas Sosial bersifat pasif , yaitu menunggu pada saat WPS datang ke Puskesmas sebagai pasien atau datang ke tempat penampungan Dinas Sosial kalau terjaring razia. Media yang sering menjadi sumber informasi adalah brosur $(62,9 \%)$ dan televisi $(51,5 \%)$. Hasil analisis chi square diperoleh nilai $\mathrm{p}=0,429$, berarti tidak terdapat hubungan yang bermakna antara keterpaparan informasi tentang IMS maupun kondom dengan penggunaan kondom pada hubungan seks yang terakhir. Hasil yang sama dilaporkan pula oleh Mulyati ${ }^{17}$ dan Wajoi. ${ }^{18}$ Hal yang berbeda dilaporkan oleh Kresno, 5 Iskandar, ${ }^{11}$ Mardjan, ${ }^{12}$ dan Suyanto, dkk ${ }^{14}$ bahwa ada hubungan yang bermakna antara penggunaan kondom dengan keterpaparan informasi.

Hasil analisis memperlihatkan bahwa persentase responden yang tidak setuju pemakaian kondom lebih besar daripada yang setuju, tetapi proporsi responden yang bersikap mendukung kondom lebih besar $(72,2 \%)$ daripada yang tidak mendukung kondom $(50 \%)$ pada penggunaan kondom saat berhubungan seks yang terakhir. Terdapat hubungan yang bermakna antara sikap terhadap penggunaan kondom dengan perilaku pemakaian kondom pada hubungan seks terakhir (Nilai $\mathrm{p}=0,027$, 
$\mathrm{OR}=2,6$ dan $(95 \% \mathrm{CI}: 1,18-5,71)$. Ini berarti bahwa responden yang mendukung kondom berpeluang menggunakan kondom pada hubungan seks terakhir 2,6 kali lebih besar daripada responden yang tidak mendukung kondom. Hal tersebut sejalan dengan temuan penelitian lain yang menemukan bahwa sikap merupakan faktor predisposisi untuk terjadinya perubahan perilaku. Untuk mewujudkan kesatuan sikap dan perbuatan nyata diperlukan faktor pendukung, antara lain meliputi ketersediaan fasilitas seperti kondom, dukungan dari petugas kesehatan. Sikap positif penggunaan kondom yang diikuti dengan perilaku pemakaian kondom dengan persentase yang relatif lebih tinggi menunjukkan bahwa responden sudah pada tahapan menerima, merespon atau mengerjakan, menghargai atau mengajak orang lain memakai kondom. Bahkan ada yang sampai pada tahap bertanggung jawab (responsible) terhadap pilihan menggunakan kondom dengan segala risikonya. Hal ini ditunjukkan oleh inisiatif pemakain kondom yang tinggi, saling berbagi kondom antara sesama WPS dan responden yang menolak tegas rhubungan seks dengan pasangan tidak bersedia memakai kondom.

Pada penelitian ini, responden yang pernah menderita IMS lebih tinggi daripada hasil penelitian WPS sebelumnya. ${ }^{6,8,13}$ Gejala IMS yang banyak diderita responden adalah keputihan yang sering dan berbau $(63,6 \%)$. Hasil uji statistik diperoleh nilai $p=0,003$ artinya, terdapat hubungan yang bermakna antara pengalaman menderita IMS dengan perilaku pemakaian kondom pada hubungan seks terakhir, sejalan dengan penelitian Soelistijani ${ }^{10}$ tahun $2003(p=0,000)$. Hasil ini berbeda dengan Iskandar ${ }^{11}$ yang melaporkan bahwa pengalaman menderita gejala IMS tidak ada hubungan yang bermakna dengan keinginan memakai kondom. Adapun nilai OR yang diperoleh berdasarkan analisis statistik adalah 3,47 (95\% CI: 1,16 - 7,7), berarti responden yang mempunyai pengalaman pernah menderita IMS mempunyai peluang untuk memakai kondom pada hubungan seks terakhir sebesar 3,47 kali dibandingkan respoden yang tidak pernah menderita IMS. Gambaran ini sesuai dengan teori Health Belief Model dan penjelasan Notoatmodjo. ${ }^{19}$

Sebagian besar responden menyatakan kondom tersedia di sekitar lokasi kerja. Hasil uji statistik diperoleh nilai $p=0,028$, berarti terdapat hubungan yang bermakna antara ketersediaan kondom dengan perilaku pemakaian kondom pada hubungan seks terakhir. Nilai $\mathrm{OR}=2,57$ (95\% CI: 1,18-7,59), berarti WPS yang di sekitar tempat kerja tersedia kondom mempunyai peluang untuk memakai kondom pada hubungan seks terakhir sebesar 2,57 kali dibandingkan WPS yang disekitar tempat kerja tidak tersedia kondom. Hal ini sejalan dengan teori Green, ${ }^{20}$ serta penelitian Mardjan ${ }^{12}$ yang menyatakan WPS yang tidak pernah mendapat kondom 8,6 kali lebih sering tidak menggunakan kondom dibandingkan WPS yang pernah mendapatkan kondom. Suyanto, dkk ${ }^{14}$ melaporkan terjadi peningkatan pemakaian kondom dari 4,05\% menjadi 78,4\% setelah dilakukan aksi pembagian kondom pada WPS, losmen, hotel, villa, dan warung makan di sekitar lokalisasi. Hal yang sama dilaporkan oleh Kresno ${ }^{5}$ bahwa rendahnya penggunaan kondom antara lain disebabkan tidak tersedianya kondom di lokalisasi. Hasil yang berbeda dilaporkan oleh Wajioi ${ }^{18}$ dalam penelitiannya di Timika Irian Jaya bahwa ketersediaan kondom tidak berhubungan dengan perilaku WPS dalam menggunakan kondom.

Hasil uji regresi logistik terhadap variabel independen yang memiliki $p$ value $<0,25$, menunjukan dua variabel yang berhubungan dengan perilaku pemakaian kondom pada hubungan seks terakhir, yaitu pengalaman menderita IMS serta variabel ketersediaan kondom. Sesuai dengan teori Health Belief Model seperti yang dijelaskan Rosenstock, ${ }^{21}$ pengalaman atau kontak sebelumnya dengan suatu penyakit merupakan variabel struktural yang mempengaruhi seseorang akan persepsi terhadap kerentanan dan keseriusan suatu penyakit yang selanjutnya akan mendorong seseorang memutuskan melakukan perilaku pencegahan tertentu untuk mengurangi ancaman penyakit tersebut.

\section{Kesimpulan}

1. Lebih dari separuh responden (60,7\%) menggunakan kondom saat berhubungan seks terakhir dengan pasangannya. Namun, konsistensi pemakaian kondom belum terjaga, pemakaian pada satu minggu terakhir $27,7 \%$; pada hari kerja terakhir $46,4 \%$.

2. Sebagian besar responden berumur $>24$ tahun $(75 \%)$ dan berpendidikan SD atau lebih rendah $(76,8 \%)$, bekerja sebagai WPS $\geq 24$ bulan $(61,6 \%)$; dengan pengetahuan IMS yang kurang $(52,7 \%)$; pernah menderita IMS selama 3 bulan terakhir $(58,9 \%)$; mendapat informasi IMS dari LSM dan TV, menyatakan peran Puskesmas dalam promosi kondom belum optimal (100\%).

3. Faktor yang berhubungan dengan perilaku pemakaian kondom pada hubungan seks terakhir adalah pengalaman menderita IMS dan ketersediaan kondom.

\section{Saran}

1. Kepada Departemen Kesehatan: (1) Mengadakan pendekatan dan advokasi secara sinambung guna mendapatkan dukungan, melalui media televisi dengan pesan kondom yang dikemas dan waktu tayang yang sesuai. (2) Membuat materi pesan di brosur tentang IMS dan kondom yang komunikatif dan mudah dimengerti WPS dengan tingkat pendidikan rendah.

2. Kepada Pemerintah Daerah Propinsi DKI Jakarta: (1) KPA Propinsi berkoordinasi dengan LSM, Dinas 
Pariwisata dan instansi instansi terkait lain mendistribusikan kondom di tempat hiburan dan penginapan seperti hotel, losmen, villa yang belum menyediakan kondom.

3. Kepada Dinas Kesehatan (1) Menjalin kemitraan dengan institusi yg terkait kegiatan pembinaa WPS melalui program dampingan berdasarkan konsep wilayah antara LSM dan Puskesmas (2) Pemberdayaan WPS dalam kegiatan penyebar luasan informasi IMS dan kondom (3) Pengembangan klinik IMS di Puskesmas sesuai pemetaan kelompok risiko tinggi.

\section{Daftar Pustaka}

1. WHO. STI/HIV Promoting Condoms in Clinics for Sexually Transmitted Infections, Regional Office for The Western Pacific.2001

2. Qomariyah, S. N. ,dkk. ISR pada Wanita Indonesia, Pusat Komunikasi kesehatan Berperspektif Jender, Ford Foundation, September 2001

3. Hakim, L. Epidemiologi Penyakit Menular Seksual, Dalam: Daili S.F, 2003, Penyakit Menular Seksual, Ed 2, Jakarta: Balai Penerbit FK UI; 2003

4. Depkes RI. Kebijaksanaan Program Pencegahan Dan Pemberantasan PMS termasuk AIDS Di Indonesia dalam Penyakit Menular Seksual, ed. Syaiful Fahmi Dailli, Jakarta: Balai Penerbit FK UI; 2003

5. Kresno, S. Penilaian Cepat Perilaku Mencari Pengobatan Pada Penderita Penyakit menular Seksual Di Jakarta, Depkes, FKM UI; 2001

6. PPK UI. Survei Surveilans Perilaku Risiko Tinggi PMS/HIV di Bali, Kupang, dan Ujung Pandang 1998, Jakarta: Indonesia HIV/AIDS and STD Prevention and Care Project, Menko Kesra dan Taskin Republik Indonesia, AusAID; 1999

7. Menteri Kesehatan. Upaya Penanggulangan HIV /AIDS Bidang kesehatan Di Propinsi Prioritas, Makalah disampaikan pada Pertemuan Evaluasi Komitmen Sentani, Hotel Borobudur Jakarta, 14 Pebruari 2005

8. Sedyaningsih, E. R. Perempuan Perempuan Kramat Tunggak, Jakarta: Pustaka Sinar Harapan, The Ford Foundation; 1999

9. Badan Pusat Statistik, ORC Macro. Survei Demografi Indonesia 2002-
2003, Calverton, Maryland, USA: ORC Macro; 2003

10. Soelistijani, D.A. Hubungan Pengetahuan Tentang HIV/AIDS Dengan Perilaku Wanita Penjaja Seks Dalam Penggunaan Kondom Seks Komersial Di Bali Tahun 2000, Tesis, FKM UI, Depok; 2003

11. Iskandar, I. Faktor-Faktor yang berhubungan dengan Keinginan Menggunakan Kondom Untuk Mencegah Terinfeksi HIV/AIDS pada WPS Di Jakarta dan Surabaya Tahun 2000, Skripsi, FKM UI, Depok; 2001

12. Mardjan. Hubungan antara Pengetahuan, Sikap dengan Praktek Mencegah Penularan HIV/AIDS WTS Di Lokalisasi Sebangkau dan Stasion Bengkayang Singkawang Kabupaten Sambas Propinsi Kalimantan Barat Tahun 1996, Tesis, FKM UI, Depok; 1996

13. Surjadi, C., dkk. Penilaian Penatalaksanaan Kasus PMS dan Penelitian Prevalensi PMS Diantara PSK Di Jakarta, Surabaya dan Manado, Jakarta : Jaringan Epidemiologi Nasional; 1998

14. Suyanto, E. dkk. Pelembagaan Penggunaan Kondom di Kalangan Pramunikmat, Yogyakarta: Pusat Penelitian Kependudukan UGM, Ford Foundation; 1997

15. Yustikawati. Faktor-Faktor yang Berhubungan Dengan Perilaku Pencarian Pengobatan Modern Infeksi Menular Seksual (IMS) Pada Wanita Penjaja Seks (WPS) Di Kabupaten Indramayu Tahun 2004, Tesis, FKM UI, Depok; 2005

16. Kalsum, N.Hubungan karakteristik Pelanggan WTS, Sumber Informasi dan Pengetahuan Tentang AIDS dengan Perilaku Pemakaina Kondom pada Pelanggan WTS Di Jakarta dan Riau Tahun 1998, Skripsi, FKM UI, Depok; 2000

17. Mulyati, S. Faktor-Faktor yang Berhubungan dengan perilaku Pemakaian Kondom secara Konsisten dalam Upaya Mencegah Penularan HIV/AIDS pada WPS di Kecamatan Cilengsi Kabupaten Bogor, Skipsi, FKM UI, Depok; 2001

18. Wajoi, H. Faktor-Faktor yang Berhubungan dengan Perilaku Penjaja Seks Komersial dan Potensi Penyakit Menular Seksual HIV/AIDS Di Kota Timika Irian Jaya, Skripsi, FKM UI, Depok; 1999

19. Notoatmodjo, S. Pendidikan Dan Perilaku Kesehatan, Jakarta: PT Rineka Cipta; 2003

20. Green,L. et al. Health Education Planning: A Diagnostik Approach, The John Hopkins University: Mayfield Publishing Co., California; 1980

21. Rosenstock, I. M. Historical Origins of The Health Belief Model, The Health Belief Model and Personal Health Behavior, editor: Becker MH; 1974 